Al-Manhaj: Jurnal Hukum dan Pranata Sosial Islam

Vol. : : 3 (1), 2021, 67-88

P-ISSN : 2686-1607

E-ISSN : 2686-4819

\title{
ANALISIS PUTUSAN HAKIM TENTANG ITSBAT CONTENCIUS PADA PENGADILAN AGAMA GUNUNG SUGIH
}

\author{
Feri Kurniawan, Abd. Qohar \\ Universitas Islam Negeri Raden Intan Lampung \\ email: ferikurniawan@gmail.com, abdul.qohar@radenintan.ac.id
}

Abstract: Marriage isbat which has been considered a solution to the settlement of a marriage under the hands offered by the Act in order to protect the rights relating to his wife and children, while the isbat or isbat contensius is a solution given to people who will divorce with a marriage that is not in marriage. record it. This research method used is a qualitative method, a type of library research, with a normative juridical approach. Based on the results of the study found, that basically a divorce that can be done before the Religious Court is a divorce from a registered marriage. In the Gunung Sugih Religious Court Decision Number: 0333 / Pdt.G / 2018 / PA.Gns concerning the Application for Itsbat Marriage, accompanied by a Divorce Claim, the judge granted the divorce suit by ratifying the marriage license first. Granting divorce proceedings on the grounds of inattention to children, spending property generated by the wife as a plaintiff, and the defendant often acts violently against the plaintiff. The judge's judgment and decision is in accordance with the value of benefit, namely guarding offspring (hifz al-nasl) and protecting property (hifz al-mal), and protecting the soul (hifz al-nafs).

Keywords: Maslahat, Itsbat Contencius, Gunung Sugih Religious Court

Abstrak: Isbat nikah yang selama ini dianggap solusi penyelesaian perkawinan di bawah tangan yang ditawarkan Undang-Undang 
dalam rangka melindungi hak-hak yang berkaitan dengan istri dan anak, sedangkan gugat isbat atau isbat contensius adalah solusi yang diberikan kepada orang yang akan bercerai dengan perkawinan yang tidak di catatkan. penelitan ini metode yang digunakan adalah metode kualitatif, jenis penelitian library research, dengan pendekatan yuridis normatif. Berdasarkan hasil penelitian ditemukan, bahwa Pada dasarnya suatu perceraian yang dapat dilakukan di hadapan Pengadilan Agama merupakan perceraian dari perkawinan tercatat. Pada Putusan Pengadilan Agama Gunung Sugih Nomor : 0333/Pdt.G/2018/PA.Gns tentang Permohonan Itsbat Nikah disertai dengan Gugatan Cerai hakim mengabulkan gugatan cerai dengan mengesahkan itsbat nikah terlebih dahulu. Mengabulkan gugatan cerai dengan alasan kurang perhatiannya terhadap anak-anak, menghabiskan harta yang dihasilkan istri sebagai penggugat, dan tergugat sering melakukan kekerasan terhadap penggugat. Pertimbangan dan putusan hakim tersebut telah sesuai dengan nilai kemaslahatan yaitu menjaga keturunan (hifz al-nasl) dan menjaga harta (hifz al-mal), dan menjaga jiwa (hifz al-nafs).

Kata Kunci: Maslahat, Itsbat Contencius, Pengadilan Agama Gunung Sugih

\section{PENDAHULUAN}

Perkawinan di bawah tangan atau tidak tercatat menimbulkan problematika hukum yang tidak sedikit. Secara ringkas bisa dikatakan bahwa dampak perkawinan yang tidak dicatatkan antara lain adalah: "Perkawinan dianggap tidak sah (hukum positif), anak hanya memiliki hubungan perdata dengan ibu dan keluarga ibunya, serta anak dan ibunya tidak berhak atas nafkah dan warisan. Pihak lelaki atau suami tidak bisa menuntut haknya atas harta bersama selama mereka berada dalam perkawinan di bawah tangan." Dampak adanya praktik nikah di 
bawah tangan, tidak hanya dirasakan oleh pelakunya, tetapi yang paling merasakan adalah anak yang lahir dari praktik nikah di bawah tangan itu. 1Padahal anak sama sekali tidak berdosa dan tidak tahu apa yang terjadi, tetapi anaklah yang dikemudian hari paling merasakan kesulitannya.

Isbat nikah yang selama ini dianggap solusi penyelesaian perkawinan di bawah tangan yang ditawarkan Undang-Undang sekarang pun tidak lepas dari permasalahan. ${ }^{2}$ Banyak hal yang harus dicermati dalam permohonan isbat nikah ini, sehingga hakim pun dalam memeriksa perkara isbat nikah disertai dengan gugatan cerai harus selektif dan berhati-hati sehingga kesan menggampangkan pengesahan nikah melalui isbat nikah dan perceraian tidak terjadi. Terkait masalah status hukum perkawinan di bawah tangan, sebagian menilai bahwa nikah di bawah tangan adalah sah secara agama sementara secara kenegaraan tidak sah.karena perkawinan yang sah hanya dapat dibuktikan dengan Akte Nikah yang dibuat oleh Pegawai Pencatat Nikah. Perkawinan di bawah tangan jelas tidak memiliki.

Beberapa kasus di Pengadilan Agama biasanya ada yang menggabungkan Isbat Nikah dengan Gugatan Perceraian. Oleh karnanya Hakim harus merespon dan menjawab segala macam Permohonan dan gugatan yang diajukan tersebut. Hukum acara di peradilan agama diatur oleh Undang-undang. Nomor 7 Tahun 1989 tentang Peradilan Agama, yang kemudian diubah dengan UU. No. 3 tahun 2006 tentang Perubahan Atas Undang-Undang Nomor

1 Departemen Agama Kebudayaan, Kamus Besar Bahasa Indonesia (Jakarta : Balai Pustaka, 1988), 1999, 2

2 M.Yahya Harahap, Hukum Acara Perdata (Sinar Grafika, 2008, ), 102 
7 Tahun 1989 Tentang Peradilan Agama. Sebagai pelaku kekuasaan kehakiman, peradilan agama menjadi tempat bagi para pencari keadilan, khususnya bagi setiap orang Islam untuk menyelesaikan persoalan yang berkaitan dengan masalah perdata Islam. Seperti halnya masalah gugat cerai, waris, harta bersama dan lain sebagainya. Perkara perceraian dapat digabungkan sekaligus dengan pengesahan perkawinan, sesuai dengan Pasal 86 UU Ayat (1) No. 7 Tahun 1989 tentang Peradilan Agama. Dari permohonan yang dimohonkan oleh penggugat dalam putusan No.0333/Pdt.G/2018/PA.Gsg dapat kita lihat bahwa penggugat memintakan dilakukannya kumulasi gugatan yakni pengesahan perkawinan serta penjatuhan talak satu ba'in sughra tergugat terhadap penggugat.

Berdasarkan uraian di atas, maka paper ini akan membahas Bagaimana tinjauan maslahah terhadap putusan Pengadilan Agama Gunung Sugih Nomor : 0333/Pdt.G/2018/PA.Gns Tentang Permohonan itsbat nikah disertai dengan gugatan cerai. Pada penelitan ini metode yang digunakan adalah metode penelitian kualitatif, jenis penelitian library research, dengan pendekatan yuridis normative, teori maslahat.

\section{PENGERTIAN ITSBAT}

Pengertian dan Dasar Hukum Itsbat Nikah. Menurut bahasa Itsbat nikah terdiri dari dua kata yaitu kata "itsbat" yang merupakan masdar atau asal kata dari "atsbata" yang memiliki arti "menetapkan", dan kata "nikah" yang berasal dari kata "nakaha" 
Feri Kurniawan, Abd. Qohar, Analisis Putusan Hakim Tentang Itsbat Contencius ... 71 yang memiliki arti "saling menikah", dengan demikian kata Itsbat nikah memiliki arti yaitu "penetapan pernikahan". ${ }^{3}$

Menurut Peter Salim kata Istbat nikah memiliki pengertian penetapan tentang kebenanaran nikah. Itsabat nikah sebenarnya sudah menjadi istilah dalam Bahasa Indonesia dengan sedikit revisi yaitu sebutan itsbat nikah. Menurut Kamus Besar Bahasa Indonesia, Itsbat nikah adalah penetapan tentang kebenaran (keabsahan) nikah. ${ }^{4}$ Itsbat nikah adalah pengesahan atas perkawinan yang telah dilangsungkan menurut syariat agama islam,akan tetapi tidak dicatat oleh KUA atau PPN yang berwenang (Keputusan Ketua Mahkamah Agung RI Nomor KMA/032/SK/2006 tentang Pedoman Tugas dan Administrasi Pengadilan). ${ }^{5}$

Pasal 2 ayat 2 menyebutkan bahwa tiap tiap perkawinan dicatat menurut peraturan perundang-undangan yang berlaku. Pencatatan perkawinan akan menimbulkan kemaslahatan umum karena dengan pencatatan ini akan memberikan kepastian hukum terkait dengan hak-hak suami/istri, kemaslahatan anak maupun efek lain dari perkawinan itu sendiri. Perkawinan yang dilakukan dibwah pengawasan atau dihadapan Pegawai Pencatat Nikah/ Kantor Usrusan Agama akan mendapatkan akta nikah sebagai bukti telah dilangsungkannya sebuah perkawinan.

Akta nikah merupakan akta autentik karena Akta Nikah tersebut dibuat oleh dan di hadapan Pegawai Pencatat Nikah

${ }^{3}$ Ahmad Rofiq, Hukum Islam di Indonesia (Jakarta: Raja Grafindo Persada, 2000), 121.

${ }_{4}$ Tim Penyusun Kamus, Kamus Besar Bahasa Indonesia ( Jakarta : balai Pystaka, Cet ke-3 1990), 339

${ }^{5}$ Djamaan Nur, Fiqih Munakahat (Semarang: CV. Toha Putra, 1993), 51. 
sebagai pejabat yang berwenang untuk melakukan pencatatan perkawinan, dibuat sesuai bentuk yang ditetapkan oleh Peraturan Pemerintah Nomor 9 Tahun 1975 dan dibuat ditempat Pegawai Pencatat Nikah/ Kantor Urusan Agama tersebut melaksanakan tugasnya. Meskipun Peraturan Perundang-Undangan sudah mengharuskan adanya Akta Nikah sebagai bukti perkawinan, namun tidak jarang terjadi suami istri telah menikah tidak mempunyai Kutipan Akta Nikah. ${ }^{6}$

Berdasarkan ketentuan pasal 7 ayat (1) Kompilasi Hukum Islam (KHI) dan Pasal $100 \mathrm{KUH}$ perdat tersebut, adanya suatu perkawinan hanya bisa dibuktikan dengan akta perkawinan atau akta nikah yang dicatat dalam register. Bahkan ditegaskan, akta perkawinan atau akata nikah merupakan satu-satunya alat bukti perkawinan. Dengan perkataan lain, perkawinan yang dicatatkan pada Pegawai Pencatat Nikah (PPN) Kantor Urusan Agama Kecamatan akan diterbitkan Akta Nikah atau Buku Nikah merupakan unsur konstitutif (yang melahirkan) perkawinan. Tanpa akta perkawinan yang dicatat, serta hukum tidak ada atau belum ada perkawinan. Sedangkan menurut Undang-Undang nomor 1 Tahun 1974 tentang Perkawinan, Akta Nikah dan pencatatan perkawinan bukan satu satunya alat bukti keberadaan atau keabsahan perkawinan, karena itu walaupun sebagai alat bukti bukan sebagai alat bukti yang menentukan sahnya

6 Supardin, Fikih Peradilan Agama di Indonesia (Rekontruksi Materi Perkara Tertentu) (Makassar: Alauddin University Press, 2014), 131 
Feri Kurniawan, Abd. Qohar, Analisis Putusan Hakim Tentang Itsbat Contencius ... 73 perkawinan, karena hukum perkawinan agamalah yang menentukan keberadaan dan keabsahan perkawinan. ${ }^{7}$

Isbat nikah merupakan produk Pengadilan Agama dalam bentuk penetapan artinya bukan pengadilan yang sesungguhnya dan diistilahkan dengan jurisdiktio voluntair. Dikatakan bukan pengadilan yang sesungguhnya, karena dalam perkara ini hanya ada pemohon, yang memohon untuk ditetapkan tentang sesuatu yaitu penetapan nikah. Perkara voluntair adalah perkara yang sifatnya permohonan dan didalamnya tidak. terdapat sangketa, sehingga tidak ada lawan. Pada dasarnya perkara permohonan tidak dapat diterima, kecuali kepentingan Undang-Undang menghendaki demikian. ${ }^{8}$

Produk perkara volunteir adalah penetapan yang nomor perkaranya diberi tanda $\mathrm{P}$, misalnya nomor 24/ Pdt.P/2014/PA/Pbr. ${ }^{9}$ Karena penetapan itu muncul sebagai produk pengadilan atas permohonan- permohonan yang tidak berlawan maka dicantum penetapan tidak akan berbunyi menghukum melainkan bersifat menyatakan (declatoir).

\section{DASAR HUKUM ISBAT NIKAH}

Pada dasarnya kewenangan isbat nikah bagi Pengadilan Agama dalam sejarahnya adalah diperuntukkan bagi mereka yang

7 Hadi Daeng Mapuna, Hukum Acara Peradilan Agama (Makassar: Alauddin University Press, 2013), 45.

8 Tim Redaksi, Kompilasi Hukum Islam Hukum Perkawinan, Kewarisan, dan Perwakafan, Pasal 2 Kompilasi Hukum Islam ( Bandung: Nuansa Aulia, 2011), 3.

9 Amir Syarifuddin., Hukum Perkawinan Islam di Indonesia Antara Fiqh Munakahat dan Undang-Undang Perkawinan (Jakarta: Prenada Media, 2006), 40-41. 
melakukan perkawinan dibawah tangan atau sebelum dikeluarkannya Undang-Undang No 1 Tahun 1974 tentang perkawinan. Jo. Peraturan pemerintah No. 9 Tahun 1975 ( penjelasan pasal 49 (2), Jo. Pasal 64 UU No 1 Tahun 1974 ) ${ }^{10}$. Namun kewenangan ini berkembang dan diperluas dengan lahirnyaKompilasi Hukum Islam (KHI).Dalam pasal 7 ayat 2 dan 3, disebutkan:" dalam hal perkawinan tidak dapat dibuktikan dengan akta nikah yang dibuat oleh Pegawai Pencatat Nikah, dapat diajukan isbat nikahnya ke Pengadilan Agama", dan pada ayat (3) disebutkan:" isbat nikah yang dapat diajukan ke Pengadilan Agama terbatas mengenai hal-hal yang berkenan dengan: Adanya perkawinan dalam rangka penyelesain perceraian; (1) Hilangnya akta nikah; (2) Adanya keraguan tentang sah tidaknya salah satu syarat perkawinan; (3) Adanya perkawinan yang terjadi sebelum berlakunya Undang-Undang No 1 Tahun 1974; (4) Perkawinan yang dilakukan oleh mereka yang tidak mempunyai halangan perkawinan menurut Undang-Undang No. 1 Tahun 1974.11

Melihat uraian pasal diatas, berarti KHI telah memberikan kopetensi absolut yang sangat luas tentang isbat nikah tanpa batasan dan pengecualian. Pencatatan perkawinan akan menimbulkan kemaslahatan umum karena dengan pencatatan ini akan memberikan kepastian hukum terkait dengan hak-hak

10 Raihan A.Rasyid, Hukum Acara Peradilan Agama (Jakarta: CV.Rajawali, 1991). 53.

11 Republik Indonesia, Undang-undang Republik Indonesia Nomor 1 Tahun 1974 tentang Perkawinan dan Kompilasi Hukum Islam, 380. 
Feri Kurniawan, Abd. Qohar, Analisis Putusan Hakim Tentang Itsbat Contencius ... 75 suami/isteri, kemaslahatan anak maupun efek lain dari perkawinan itu sendiri. ${ }^{12}$ Perkawinan yang dilakukan di bawah pengawasan atau di hadapan Pegawai Pencatat Nikah/Kantor Urusan Agama akan mendapatkan Akta Nikah sebagai bukti telah dilangsungkannya sebuah perkawinan.

Sedangkan dari hokum syar'i sendiri secara eksplisit memang tidak satupun nash baik Al-Quran maupun Hadits yang menyatakan keharusan adanya pencatatan perkawinan. Wajibnya pencacatan sebagai salah satu syarat sahnya perkawinan dalam islam beranalogi atau berqiyas kepada ayat yang mewajibkan pencacatan dalam transaksi hutang-piutang. Perkawinan sejatinya merupakan transaksi yang amat penting, bahkan jauh lebih penting dari transaksi yang lainnya dalam kehidupan manusia.

Kondisi seperti sekarang ini, pencatatan perkawinan menjadi sebuah keharusan bagi seseorang, hal ini disebabkan karena banyak sekali mudharat yang akan ditimbulkan jika tidak dilakukan pencatatan. Islam menggariskan bahwa setiap kemudharatan itu sedapat mungkin harusdi hindari, sebagaimana ungkapan sebuah kaedah fikih yang berbunyi : "Kemudharatan harus dihilangkan".

\section{SYARAT-SYARAT ITSBAT NIKAH}

Tentang syarat itsbat nikah ini tidak dijelaskan dalam kitab fiqih klasik maupun kontemporer. Akan tetapi syarat itsbat nikah ini dapat dianalogikan dengan syarat pernikahan. Hal ini 
karena itsbat nikah (penetapan nikah) pada dasarnya adalah penetapan suatu perkawinan yang telah dilakukan sesuai dengan ketentuan yang terdapat dalam syariat Islam. Bahwa perkawinan ini telah dilakukan dengan sah yaitu telah sesuai dengan syarat dan rukun nikah akan tetapi pernikahan ini belum dicatatkan ke pejabat yang berwenang yaitu Pegawai Pencatat Nikah (PPN). Maka untuk mendapatkan penetapan (pengesahan nikah) harus mengajukan terlebih dahulu perkara permohonan itsbat nikah ke Pengadilan Agama.

\section{TUJUAN ITSBAT NIKAH}

Pencatatan perkawinan bertujuan untuk mewujudkan ketertiban perkawinan dalam masyarakat. Ini merupakan upaya yang diatur melalui perundang-undangan untuk melindungi martabat dan kesucian perkawinan, lebih khusus bagi perempuan dalam kehidupan rumah tangga. Melalui pencatatan perkawinan yang dibuktikan dengan akta nikah, yang masing-masing suami isteri mendapat salinannya, apanila terjadi perselisihan atau percekcokan diantara mereka, atau salah satu tidak bertanggung jawab, maka yang lain dapat melakukan upaya hukum guna mempertahankan atau memperoleh hak masing-masing. Karena dengan akta tersebut, suami istri mempunyai bukti otentik atas perbuatan hukum yang telah mereka lakukan.

Adapun beberapa akibat hukum akibat perkawinan tidak dicatatkan diantaranya; (1) Perkawinan Dianggap Tidak Sah Meskipun perkawinan dilakukan menurut Agama dan keprcayaan, 
Feri Kurniawan, Abd. Qohar, Analisis Putusan Hakim Tentang Itsbat Contencius ... 77 namun dimata negara perkawinan tersebut dianggap tidak sah jika belum dicatat oleh Kantor Urusan Agama (KUA) atau Kantor Catatan Sipil. (2) Anak Hanya Mempunyai Hubungan Perdata Dengan Ibu dan Keluarga Ibu Anak-anak yang dilahirkan diluar perkawinan atau perkawinan yang tidak tercatat, selain dianggap anak tidak sah, juga hanya mempunyai hubungan perdata dengan Ibu atau keluarga Ibu (Pasal 42 dan 43 Undang-Undang Perkawinan). (3) Anak dan Ibunya Tidak Berhak Atas Nafkah dan Warisan Akibat lebih jauh dari perkawinan yang tidak dicatat adalah baik istri maupun anak-anak yang dilahirkan dari perkawinan tersebut tidak berhak menuntut nafkah ataupun warisan dari ayahnya. ${ }^{13}$

\section{SEBAB-SEBAB PERMOHONAN ITSBAT NIKAH DI PENGADILAN AGAMA}

Adapun sebab-sebab yang melatarbelakangi adanya permohonan itsbat nikah disertai dengan perceraian ke PA itu sendiri, dalam praktek, khususnya di PA pihak-pihak yang mengajukan permohonan Itsbat nikah dapat ditemukan kebanyakannya:14 (1) Adanya perkawinan yang terjadi sebelum berlakunya UU No 1 Th 1974. Untuk hal ini biasanya dilatarbelakangi; Untuk mengesahkan Pernikahan terdahulu, dan Pemutusan pernikahan menurut Hukum yang berlaku. (2) Adanya perkawinan yang terjadi sudah berlakunya UU no 1 Th 1974. Ini

13 Undang-undang No.1 Tahun 1974, Tentang Perkawinan.

14 Linda Firdawaty, Hukum Acara Peradilan Agama (Bandar Lampung: Permata Printing Solutions, 2009), 39. 
biasanya dilatarbelangi oleh; Karena Akta Nikah hilang, dan karena tidak punya Akta Nikah.

\section{KEPASTIAN HUKUM ITSBAT NIKAH TERHADAP STATUS HARTA PERKAWINAN}

Sejalan dengan kepastian hukum itsbat nikah terhadap status perkawinan, status anak, maka itsbat nikah juga akan memberikan kepastian hukum terhadap status harta perkawinan. Dengan adanya itsbat nikah, penyelesaian terhadap sengketa harta perkwainan dapat merujuk pada ketentuan peraturan perundang undangan yang ada, seperti ketentuan Bab VII UU Nomor 1 Tahun 1974 mengatur tentang harta benda dalam perkawinan. Pada Pasal 35 disebutkan bahwa harta benda yang diperoleh selama perkawinan menjadi harta Bersama; harta bawaan dari masingmasing suami dan istri dan harta yang diperoleh masing-masing sebagai hadiah atau warisan adalah dibawah penguasaan masingmasing sepanjang para pihak tidak menentukan lain.

Dan dalam Pasal 36 dirumuskan bahwa mengenai harta Bersama, suami atau istri dalam bertindak atas persetujuan kedua belah pihak; mengenai harta bawaan masing-masing, suami dan istri mempunyai hak sepenuhnya untuk melakukan perbuatan hukum mengenai hartanya. Apabila pasangan suami istri itu perkawinannya putus karena perceraian, maka masing-masing pihak akan mendapatkan separuh dari harta Bersama(gono gini) yang mereka peroleh selama dalam ikatan perkawinan sepanjang tidak ditentuakan lain dalam perjanjian kawin (Pasal 37 Undang 
Feri Kurniawan, Abd. Qohar, Analisis Putusan Hakim Tentang Itsbat Contencius ... 79 Undang No 1 Tahun 1974 tentang perkawinan jo.Pasal 97 Kompilasi Hukum Islam).

\section{ITSBAT NIKAH CONTENTIOUS DI PENGADILAN AGAMA GUNUNG SUGIH LAMPUNG TENGAH}

Berdasarkan hasil penelitian, data pengadilan kebanyakan perkara yang masuk adalah perkara perceraian. Di bawah ini penulis akan menyajikan data perkara yang telah masuk ke Pengadilan Agama Gunung Sugih dari bulan Januari 2017 sampai bulan Desember tahun 2019. Di bawah ini penulis menyajikan data dalam bentuk tabel.

Tabel 1.1 Perkara yang Diterima dari Oktober 2017Setember 2019

\begin{tabular}{|c|l|c|c|c|}
\hline \multirow{2}{*}{ NO } & \multirow{2}{*}{ Bulan } & \multicolumn{3}{|c|}{ Isbat Nikah di sertai gugatan cerai } \\
\cline { 3 - 5 } & & 2017 & 2018 & 2019 \\
\hline 1 & Januari & 1 & 1 & 2 \\
\hline 2 & Februari & 2 & 1 & 2 \\
\hline 3 & Maret & 1 & 1 & 3 \\
\hline 4 & April & 1 & 1 & 1 \\
\hline 5 & Mei & 2 & 2 & 2 \\
\hline 6 & Juni & - & 1 & 3 \\
\hline 7 & Juli & 1 & 2 & 3 \\
\hline 8 & Agustus & - & 1 & 1 \\
\hline 9 & September & - & 2 & 1 \\
\hline 10 & Oktober & 2 & 1 & 1 \\
\hline 11 & November & - & 3 & 1 \\
\hline 12 & Desember & 3 & 1 & 1 \\
\hline Jumlah & & 13 & 17 & 21 \\
\hline
\end{tabular}




\section{Total $=51$ Perkara Diterima}

\section{ANALISIS PUTUSAN HAKIM TENTANG ITSBAT CONTENCIUS PADA PENGADILAN AGAMA GUNUNG SUGIH}

Pada dasarnya adanya peraturan mengenai pencatatan perkawinan bertujuan untuk mewujudkan ketertiban perkawinan dalam masyarakat. Perkawinan itu sendiri merupakan kegiatan muamalah yang dimana terdapat akad didalamnya antara kedua belah pihak, maka dari itu apabila terdapat akad diantara dua orang yang berperkara maka Allah SWT menganjurkan untuk mencatatkannya, hal ini sama dengan hal hutang piutang. Dengan begitu dapat dikatakan bahwa kegiatan muamalah dalam hal akad hutang piutang saja yang memiliki batas waktu harus dicatatkan apalagi kegiatan dalam akad pernikahan yang merupakan mitsaqan ghalizan tentunya membutuhkan sebuah catatan agar dapat diakui keabsahannya dan memiliki kekuatan hukum.

Termaktub dalam ayat dalam Al-Qur'an yang menyatakan bahwa bahwa kegiatan muamalah itu harus dicatatkan yaitu pada surat Al-Baqarah ayat 282, Artinya : "Hai orang-orang yang beriman, apabila kamu bermu'amalah tidak secara tunai untuk waktu yang ditentukan, hendaklah kamu menuliskannya."

Menurut analisis penulis kata tadayantum, yang dalam ayat diatas diterjemahkan dengan bermuamalah, terambil dari kata dain. Kata ini memiliki banyak arti, tetapi makna setiap kata yang dihimpun oleh huruf-huruf kata dain itu (yakni dal, ya', dan nun) selalu menggambarkan hubungan antar dua pihak, salah satunya 
Feri Kurniawan, Abd. Qohar, Analisis Putusan Hakim Tentang Itsbat Contencius ... 81 berkedudukan lebih tinggi dari pihak lain. Kata ini antara lain bermakna hutang, pembalasan, ketaatan, dan agama. Kesemuanya menggambarkan hubungan timbal balik itu, atau dengan kata lain bermuamalah. Termasuk dalam akad pernikahan merupakan perbuatan muamalah yang membutuhkan pencatatan sehingga mendapat keukuatan hukum dan diakui oleh negara.

Oleh karena itu maka dapat ditegaskan bahwa, pencatatan perkawinan dan itsbat nikah merupakan ketentuan yang perlu diterima dan dilaksanakan oleh semua pihak. Karena ia memiliki landasan metodologis yang cukup kokoh, yaitu maslahah mursalah yang dibangun atas dasar kajian induktif. Seluruh hukum yang ditetapkan Allah SWT atas hamba-Nya dalam bentuk suruhan atau larangan adalah mengandung mashlahah. Tidak ada hukum syara yang tidak memiiki nilai maslahah.

Pada hakikatnya perintah seluruh perntah Allah yang sifatnya anjuran atau kewajiban kepada manusia mengandung manfaat untuk dirinya baik secara langsung atau tidak. Manfaat itu ada yang dapat dirasakannya pada waktu itu juga dan ada yang dapat dirasakan sesudahnya. Begitu pula dengan semua larangan Allah SWT untuk dijauhi manusia. Di balik larangan itu terkandung kemaslahatan, yaitu terhindarnya manusia dari kebinasaan atau kerusakan.

Sebelum menganalisis lebih jauh tentang nilai-nilai kemaslahatan yang terdapat dalam putusan Pengadilan Agama Gunung Sugih Nomor : 0333/Pdt.G/2018/PA.Gns tentang Permohonan Itsbat Nikah Disertai dengan Gugatan Cerai. Penulis 
akan terlebih dahulu menjelaskan mengenai definisi maslahah dalam Islam.

Kata maslahah itu sendiri berasal dari kata so-la-ha dengan penambahan "alif" di awalnya yang secara arti kata berarti "baik" lawan dari kata "buruk" atau "rusak". Pengertian maslahah dalam bahasa Arab berarti "perbuatan-perbuatan yang mendorong kepada kebaikan manusia". Dalam artinya yang umum adalah setiap segala sesuatu yang bermanfaat bagi manusia, baik dalam arti menarik atau menghasilkan seperti menghasilkan keuntungan atau kesenangan atau dalam arti menolak/menghindarkan seperti menolak kemudaratan/kerusakan. Jadi setiap yang mengandung manfaat patut disebut maslahah. Dengan begitu maslahah itu mengandung dua sisi, yaitu menarik atau mendatangkan kemaslahatan dan menolak atau menghindarkan kemudharatan.

Al-Ghazali menjelaskan bahwa pada hakikatnya maslahah itu berarti sesuatu yang mendatangkan manfaat (keuntungan) dan menjauhkan mudharat (kerusakan). Sedangkan tujuan syara' dalam menetapkan hukum itu ada lima, yaitu: memelihara agama, memelihara jiwa, memelihara akal, memelihara keturunan, dan memelihara harta.

Al-Khawarizmi memberikan defenisi mengenai maslahah yang hampir sama dengan al-Ghazali di atas, yaitu memelihara tujuan syara" (dalam menetapkan hukum) dengan cara menghindarkan kerusakan dari manusia. Defenisi ini memiliki kesamaan dengan defenisi al-Ghazali dari segi arti dan tujuannya, karena menolak kerusakan itu mengandung arti menarik 
kemanfaatan, dan menolak kemaslahatan berarti menarik kerusakan.

Dari berbagai defenisi mengenai maslahah dengan berbagai rumusan yang berbeda akan tetapi dapat penulis simpulkan bahwa maslahah itu adalah sesuatu yang dipandang baik oleh akal sehat karena mendatangkan kebaikan dan menghindarkan keburukan (kerusakan) bagi manusia, sejalan dengan tujuan syara' dalam menetapkan hukum.

Maslahah dalam pengertian bahasa merujuk pada tujuan pemenuhan kebutuhan manusia dan karenanya mengandung pengertian untuk mengikuti syahwat atau hawa nafsu. Sedangkan pada maslahah dalam artian syara' yaitu memelihara agama, jiwa, akal, keturunan, dan harta benda, tanpa melepaskan tujuan pemenuhan kebutuhan manusia, yaitu mendapatkan kebahagiaan dan menghindarkan kerusakan.

Sedangkan makna dari kata mursalah berarti terlepas atau bebas dari keterangan yang menunjukkan boleh atau tidak bolehnya dilakukan. Ada beberapa defenisi yang berbeda tentang kata maslahah mursalah, namun masing-masing memiliki kesamaan dan pengertiannya. Al-Ghazali merumuskan maslahah mursalah sebagai; Apa-apa (maslahah) yang tidak ada bukti baginya dari syara" dalam bentuk nash tertentu yang membatalkannya dan tidak ada yang memerhatikannya.

Definisi mengenai mursalah juga dijelaskan oleh Ibnu Qudamah dari ulama Hambali yang mengartikan maslahah mursalah adalah maslahah yang tidak ada bukti petunjuk tertentu yang membatalkannya dan tidak ada pula yang memerhatikannya. 
Dari paparkan diatas maka dapat simpulkan bahwa yang dikasud dengan maslahah mursalah adalah. Pertama, sesuatu yang baik menurut akal dengan pertimbangan dapat mewujudkan kebaikan dapat menghindarkan keburukan bagi manusia. Kedua, apa yang baik menurut akal itu, juga selaras dan sejalan dengan tujuan syara" dalam menetapkan hokum. Ketiga, apa yang baik menurut akal dan selaras pula dengan tujuan syara' tersebut tidak ada petunjuk syara' secara khusus yang menolaknya, juga tidak ada petunjuk syara' yang mengakuinya.

Menurut analisis penulis teori maslahah mursalah tersebut adalah bertujuan untuk menjauhkan setiap kemudharatan terhadap pernikahan nantinya. Dengan teori ini maka dapat dilihat bahwa pentingnya pencatatan pernikahan maupun itsbat nilah dalam hubungan suami istri. Hal ini bertujuan agar status pernikahan dan perceraian tersebut mendapatkan bukti otentik dan legal secara hukum yang berlaku di Indonesia sehingga apa yang menjadi hak dan kewajiban para berperkara Putusan Pengadilan Agama Gunung Sugih Nomor : 0333/Pdt.G/2018/PA.Gns tentang Permohonan Itsbat Nikah Disertai dengan Gugatan Cerai mendapat kekuatan hukum.

Itsbat nikah baik dalam perkara contentious maupun voluntaire adalah tidak data diartikan sebagai suatu bentuk intervensi pemerintah atau negara dalam urusan privasi keluarga melainkan dapat diartikan sebagai suatu upaya negara dalam melindungi dan menjamin terpenuhinya hak-hak sosial warga negara, khususnya pasangan suami istri, serta anak-anak yang 
Feri Kurniawan, Abd. Qohar, Analisis Putusan Hakim Tentang Itsbat Contencius ... 85 lahir dari perkawinan itu. Terpenuhinya hak-hak sosial itu, akan melahirkan tertib sosial sehingga akan tercipta keserasian dan keselarasan hidup bermasyrakat. Jadi dilihat dari pentingnya itsbat nikah contentious ini adalah untuk melindungi hak-hak keperdataan dari sang istri maupun hak perdata anak yang lahir dari pernikahan tersebut. Sehingga kemaslahatan tetap terwujud dengan adanya itsbat contentious tersebut.

Dalam Putusan Pengadilan Agama Gunung Sugih Nomor : 0333/Pdt.G/2018/PA.Gns tentang Permohonan Itsbat Nikah Disertai dengan Gugatan Cerai, termaktub bahwa alasan penggugat mengajukan Gugatan Itsbat adalah sejak bulan Januari 2009 rumah tangga Pemohon Itsbat nikah sekaligus Penggugat Gugat Cerai dan Termohon itsbat nikah sekaligus Tergugat gugat cerai mulai terjadi perselisihan dan pertengkaran yang disebabkan oleh Termohon Itsbat nikah sekaligus Tergugat guat cerai kurang memberikan perhatian dan kasih saying terhadap anak-anak lebih sibuk dengan kemalasannya tidak mau bekerja (pengangguran) dan hanya bisa menghabiskan hasil. Pemohon itsbat nikah sekaligus Pengugat gugat cerai di luar negeri saja. Menurut analisis penulis adanya gugatan itsbat yang diajukan oleh istri sebagai penggugat sesuai dengan tujuan pensyariatan yakni menjaga keturunan (hifz al-nasl) dan menjaga harta (hifz al-mal) karena melalui keterangan dan bukti penggugat menyatakan sikap suami sebagai tergugat yang malas dan hanya memanfaatkan hasil kerja istri bertentangan dengan tujuan pensyariatan yakni menjaga keturunan (hifz al-nasl) dan menjaga harta (hifz al-mal). 
Selain itu sikap tergugat yang sering menganggur dan merorong penggugat, juga sering memfitnah dan sering melakukan penganiayaan (menendang dan mencekik) Pemohon Itsbat nikah sekaligus Penggugat gugat cerai, yang berakibat Pemohon itsbat nikah sekaligus Penggugat gugat Cerai dan Termohon Itsbat nikah sekaligus Tergugat gugat cerai pisah rumah ke tempat tinggal masing-masing orang tua. Dari keterangan tersebut penulis menganalisis bahwa adanya KDRT yang dilakukan tergugat kepada penggugat jauh dari tujuan pensyariatan yakni menjaga jiwa (hifz al-nafs).

Melihat runtutan keterangan yang terjadi dalam perkara Nomor : 0333/Pdt.G/2018/PA.Gns tentang Permohonan Itsbat Nikah Disertai dengan Gugatan Cerai yang memberi putusan cerai kepada status perkawinan tidak tercatat merupakan sebuah kemaslahatan. karena apabila pernikahan tersebut tidak dicatatkan maka status pernikahan tersebut secara hukum tidak legal dan majelis hakim tidak akan dapat berbuat apaapa terhadap kasus pernikahan semacam ini apabila terjadi hal-hal yang tidak diinginkan di kemudian hari seperti yang telah penulis paparkan sebelumnya.

Melihat dari banyaknya maslahah yang didapat dengan mengajukan itsbat nikah terhadap pernikahan yang tidak dicatatkan, maka menurut analisis penulis Nomor : 0333/Pdt.G/2018/PA.Gns tentang Permohonan Itsbat Nikah Disertai dengan Gugatan Cerai telah sesuai dengan nilai-nilai kemaslahatan mencakup tujuan pensyariatan yakni menjaga 
keturunan (hifz al-nasl), menjaga harta (hifz al-mal) dan menjaga jiwa (hifz al-nafs).

\section{KESIMPULAN}

Pada dasarnya suatu perceraian yang dapat dilakukan di hadapan Pengadilan Agama merupakan perceraian dari perkawinan tercatat. Pada Putusan Pengadilan Agama Gunung Sugih Nomor : 0333/Pdt.G/2018/PA.Gns tentang Permohonan Itsbat Nikah disertai dengan Gugatan Cerai hakim mengabulkan gugatan cerai dengan mengesahkan itsbat nikah terlebih dahulu dengan alasan kurang perhatiannya terhadap anak-anak, menghabiskan harta yang dihasilkan istri sebagai penggugat, dan tergugat sering melakukan kekerasan terhadap penggugat. Pertimbangan dan putusan hakim tersebut telah sesuai dengan nilai kemaslahatan yaitu menjaga keturunan (hifz al-nasl) dan menjaga harta (hifz al-mal), dan menjaga jiwa (hifz al-nafs).

\section{DAFTAR PUSTAKA}

Ali, Zainuddin, Hukum Perdata Islam di Indonesia, Jakarta: Sinar Grafika, 2007.

Departemen Agama Kebudayaan, Kamus Besar Bahasa Indonesia, Jakarta: Balai Pustaka, 1988.

Firdawaty, Linda, Hukum Acara Peradilan Agama, Bandar Lampung: Permata Printing Solutions, 2009.

Ghani, Abdullah Abdul, Himpunan Perundang-Undangan Dan Peraturan Peradilan Agama, Jakarta: Gunung Jati, 2002.

Harahap, M. Yahya, Hukum Acara Perdata, Jakarta : Sinar Grafika, 2008.

Manan, Abdull, Penerapan Hukum Acara Perdata di Lingkungan Perdilan Agama, Jakarta : Yayasan Al-Hikmah, 2000 
Mapuna, Hadi Daeng, Hukum Acara Peradilan Agama, Makassar: Alauddin University Press, 2013.

Nur, Djamaan, Fiqih Munakahat, Semarang: CV. Toha Putra, 1993.

Rasyid, Raihan. A, Hukum Acara Peradilan Agama, Jakarta : CV.Rajawali, 1991.

Republik Indonesia, Undang-undang Nomor 3 Tahun 2006 tentang Perubahan UU.Nomor 7 tahun 1989 tentang Peradilan Agama.

Republik Indonesia, Undang-Undang Republik Indonesia Nomor 1 Tahun 1974 tentang Perkawinan \& Kompilasi Hukum Islam.

Rofiq, Ahmad, Hukum Islam di Indonesia Jakarta: Raja Grafindo Persada, 2000.

Supardin, Fikih Peradilan Agama di Indonesia (Rekontruksi Materi Perkara Tertentu), Makassar: Alauddin University Press, 2014.

Syarifuddin, Amir., Hukum Perkawinan Islam di Indonesia Antara Fiqh Munakahat dan Undang-Undang Perkawinan, Jakarta: Prenada Media, 2006.

Tim Penyusun Kamus, Kamus Besar Bahasa Indonesia Jakarta: balai Pustaka,1990.

Tim Redaksi, Kompilasi Hukum Islam Hukum Perkawinan, Kewarisan, dan Perwakafan, Pasal 2 Kompilasi Hukum Islam, Bandung: Nuansa Aulia, 2011.

Yafie, Ali dkk. Mimbar Hukum Aktualisasi Hukum Islam, Jakarta: Intermasa, 1993. 